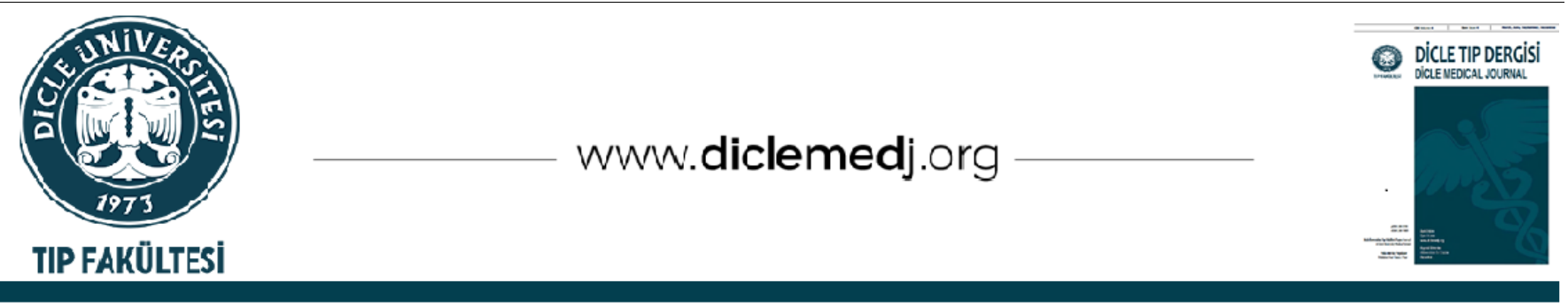

Derleme / Review

\title{
COVID-19 ve Fiziksel Tip ve Rehabilitasyon
}

\author{
İbrahim Batmaz $D_{1}$, Mehmet Karakoç $D_{2}$ \\ 1 Dicle Üniversitesi Fiziksel Tıp ve Rehabilitasyon AD Diyarbakır, Türkiye \\ Geliş: 21.09.2021; Kabul Tarihi: 29.09.2021
}

Öz

Koronavirüs Hastalığı 2019 (COVID-19); temelde solunum sistemi enfeksiyonu şeklinde hafif hastalıktan ciddi sepsis tablosuna kadar değișebilmektedir. Hastalık; kas-iskelet, nörolojik, kardiyopulmoner gibi farklı sistemik tutulumlarla seyredebilmektedir. Birçok hasta yaygın kas ve eklem ağrıları tanımlamakta ve hastalık miyozit ve sarkopeni gibi kas problemlerine neden olabilmektedir.

Uzun süreli hareketsizlik hastalarda sekonder komplikasyonlara yol açabilmektedir. Hastalıklara bağlı gelişebilecek engelliliği azaltmak, rehabilitasyonun en önemli amaçlarındandır. Pandemi, Fiziksel Tıp ve Rehabilitasyon (FTR) alanında; yatan ve ayaktan poliklinik hastalarına sunulan hizmetin değișmesi, hastalığın subakut ve kronik dönemde gerektirebileceği rehabilitasyon ihtiyacı ve devam eden pandemi sürecinde COVID-19 semptomlarını tanıma ve hareket sistemi sorunlarının ayırıcı tanısında yer verme bilincinin oluşması gibi sonuçlar yaratmıştır.

Anahtar kelimeler: COVID-19, fiziksel ve rehabilitasyon, ağrı

\section{COVID-19 and Physical Medicine and Rehabilitation}

\section{Abstract}

Coronavirus Disease 2019 (COVID-19); Basically, it can vary from mild illness in the form of respiratory system infection to severe sepsis. Disease; It can progress with different systemic involvements such as musculoskeletal, neurological, cardiopulmonary. Many patients describe widespread muscle and joint pain, and the disease can cause muscle problems such as myositis and sarcopenia.

Prolonged inactivity may lead to secondary complications in patients. Reducing the disability that may develop due to diseases is one of the most important goals of rehabilitation. In the field of Pandemic, Physical Medicine and Rehabilitation (FTR); The change in the service provided to inpatient and outpatient outpatients, the need for rehabilitation that the disease may require in the subacute and chronic periods, and the awareness of recognizing the symptoms of COVID-19 during the ongoing pandemic and including it in the differential diagnosis of movement system problems have created results.

Keywords: COVID-19, physical and rehabilitation, pain.

DOI: 10.5798/dicletip.1004987

Yazışma Adresi / Correspondence: Ibrahim Batmaz, Dicle Üniversitesi Fiziksel Tıp ve Rehabilitasyon AD Diyarbakır, Türkiye e-mail: ibrahimbatmaz82@hotmail.com 


\section{GíRiş}

Pandemi sürecinde FTR hizmetlerinde gerek yatan hasta bölümünde gerek ayaktan fizik tedavi ünitesinde zorunlu aksamalar meydana gelmiştir. Diğer branşlarda olduğu gibi verilen sağlık hizmeti azalmıştır.

Öte yandan COVID-19 hastalarının çoğunda hastalı hafif veya komplikasyonsuz seyrederken, bir kısmında hastaneye yatış ve oksijen desteği gerektiren ciddi hastalıklar gelişmekte ve \%5'i yoğun bakım ünitesinde takip edilmektedir ${ }^{1}$. COVID-19 ile ilgili yayınlarda, ülkemiz ve dünyadaki klinik tecrübelerde, hastalığın solunum sistemi tutulumu dışında; kardiyovasküler sistemi etkilediği, nörolojik sorunlar oluşturabildiği, kas iskelet sistemi sorunlarına yol açabildiği ve psikiyatrik problemlere neden olabildiği görülmektedir. $\mathrm{Bu}$ sistemlerin sekelle sonuçlanması durumunda, hastaların rehabilitasyona ihtiyaç göstermesi kaçınılmazdır².

\section{COVID-19 ve pulmoner rehabilitasyon}

Hastalık en sık solunum sistemi tutulumu ile seyretmektedir ${ }^{3}$. Akut olgularda, hastanın bulunduğu klinik evreye (hafif hastalık, pnömoni, ciddi pnömoni) göre, bireysel ihtiyaç belirlenmelidir. Ciddi ve kritik COVID-19 hastalarının durumu değişkenlik göstermektedir. COVID-19 hastalarında pulmoner rehabilitasyonun (PR) amacl, nefes darlı̆̆ı semptomlarını iyileștirmek, kaygıyı gidermek, komplikasyonları azaltmak, sakatlığı en aza indirmek, işlevi korumak ve yaşam kalitesini artırmaktır. PR her hastaya özel olarak ayarlanmalıdır ${ }^{4}$.

Akut süreçte PR'un etkinliği konusunda yeterli kanıt bulunmamaktadır. Hastalık evrelerine göre belirlenen PR yaklașımları uygulanabilir. Hastalığın bulaşıcılığı, hızlı değişen klinik tablosu rehabilitasyon yaklaşımlarında daha dikkatli olunmasını gerektirmektedir. Bununla birlikte ne zaman uygulanmasının hastaya daha fazla yarar getireceği bilinmemektedir ${ }^{5}$.

Hafif hastalık, görüntülemede pnömoni belirtileri olmayan hafif semptomlar olarak tanımlanır. Hafif hastalıkta PR olarak eğitim, hava yolu temizleme teknikleri, fiziksel egzersiz, nefes egzersizleri, aktivite rehberliği ve kaygı yönetimi düşünebilir ${ }^{6,7}$.

Orta ve şiddetli hastalıkta hastaların hastaneye yatırılması ve izlenmesi gerekir. Mümkün olduğunda COVID-19'un akut tedavisi sırasında PR düşünülmelidir. Kronik akciğer rahatsızlıklarının akut alevlenmesinde, pulmoner rehabilitasyon, yaşam kalitesi ve egzersiz kapasitesi üzerinde orta-büyük olumlu etkileri olmaktadır. Genel olarak, akut hastalıkta PR, mortalite artışı olmadan güvenli görünmektedir ve COVID-19 için güvenle uygulanabilir ${ }^{8-10}$.

Sonuç olarak, PR bize COVID-19 ile mücadelede ek araçlar sağlar ve postür, hava yolu temizleme tekniği, oksijen takviyesi, nefes egzersizleri, germe, manuel terapi ve fiziksel aktiviteyi içerebilir.

\section{COVID-19 ve kardiyak rehabilitasyon}

COVID-19 kardiyovasküler sistemde; vasküler inflamasyon, akut hipoksik miyokardial yaralanma, miyokardit, arteryel ve venöz tromboembolizm ve kardiak aritmi gibi sorunlara yol açabilmektedir ${ }^{11,12}$.

Kardiyak açıdan etkilenmiş olan COVID-19 hastalarında, hem sekonder korunma hem de bireysel fonksiyonun geri kazanılması amacıyla taburculuk sonrasında uzun süreli rehabilitasyon programlarına ihtiyaç duyulabilir. Bu bireyler, uygulanacak kapsaml kardiyak rehabilitasyon programları sayesinde önceki toplumsal rollerine dönebilirler. COVID19'a bağlı kardiyovasküler sekel gelişen 
hastalar kardiyak rehabilitasyon programına alınmadan önce kardiyolog tarafından değerlendirilmeli, medikal öykü, fizik muayene, EKG, semptom sinırlı egzersiz testi ve ekokardiyografi değerlendirmeleri yapılmalıdır. Bunun dışında bazı olgularda 24 saatlik holter EKG, stres ekokardiyografi, akciğer grafisi, radyonüklid veya invaziv görüntülemelere de ihtiyaç duyulabilir. Yapılan değerlendirmeler sonucunda hastada kardiyak rehabilitasyon açısından kontrendikasyon bulunup bulunmadığ belirlenmelidir ${ }^{13}$.

Aerobik egzersizler devamlı tarzda uygulanabileceği gibi aralıklı tarzda da uygulanabilir. Kalp yetmezliği hastalarında yüksek yoğunluklu aralıklı egzersiz ve devam egzersizin, fonksiyonel kapasiteye etkisi açısından bir fark gösterilememiştir. Egzersizler ilk ay düşük yoğunlukta başlanmalı ve kalp yetmezliği bulgularının artışı açısından hasta gözlemlenmelidir ${ }^{14}$.

\section{COVID-19 ve Kas-İskelet Sistemi Ağrısı}

Hastanelere ve tıbbi kaynaklara erişimin azalması nedeniyle COVID-19 salgını sırasında ağrı yönetimi önem kazanmaktadır. COVID-19 esas olarak akciğerleri ve iç organları etkilese de, kreatin kinaz ve laktat dehidrojenaz düzeylerinde belirgin yükselme ile bu hastalıktan kas-iskelet sistemi hasarı bildirilmiştir. Patofizyolojisinin esas olarak aşırı inflamatuar yanıttan kaynaklandığına inanılmaktadır ${ }^{15}$. Buna ek olarak, artan trombotik olay periferik damardan kasa zayıf vaskülarizasyona neden olabilmektedir ${ }^{16}$.

Yüksek kreatinin kinaz ve laktat dehidrojenaz ile karakterize, ciddi COVID-19 hastalı̆̆ olan 214 hastanın 17'sinde iskelet kası hasarı görülmüştür ${ }^{17}$. Ek olarak, COVID-19 nedeniyle hastaneye kaldırılan ve yatışının 9. gününde alt ekstremitelerde ağrı ve güçsüzlük ile pozitif hassasiyet gösteren bir hasta vaka raporu bulunmaktadır. Karaciğer enzimleriyle birlikte yükselmiş miyoglobin, kreatinin kinaz ve laktat dehidrojenaz rabdomiyolizi düşündürebilir ${ }^{18}$.

COVID-19 enfeksiyonuna bağlı gelişen ağrıların tedavisinin yanı sıra hastaların öncesinde var olan ağrılarının kontrol altına alınması amacıyla kullanılacak olan medikal tedavilere yönelik henüz kabul edilmiş kanıta dayalı bir yöntem bulunmaması, analjezik seçimini zorlaştırmaktadır. Bu nedenle daha çok klinik gözlemsel çalışmalar ve uzman görüşleri dikkate alınmaktadır ${ }^{19}$.

COVID-19 hastalarında hastane izolasyonu ve yoğun bakım sürecinde gelișen immobilizasyona bağlı, viral kaynaklı miyaljilere benzer şekilde kas ağrıları oluşabilmektedir. Ayrıca uzun dönemde immobilizasyona sekonder olarak kas fibrillerinde kısalma, eklem kontraktürleri ve kemik mineral dansitesinde azalma gibi komplikasyonlar hastalarda ciddi disabilite nedeni olabilmektedir. $\mathrm{Bu}$ hastalarda immobilizasyona bağlı gelişebilecek komplikasyonların önlenmesi ve fiziksel aktivitenin sağlanabilmesi için egzersiz tedavileri önem kazanmaktadır. Egzersiz programları, hastanın mental ve fiziksel durumuna, komorbid hastalıklarına ve hastalığın ciddiyetine göre farklılık gösterebilmektedir. Bu faktörler göz önünde bulundurularak, bireysel egzersiz programları oluşturulmalı, egzersiz seansları sırasında hastalar takip edilerek egzersizin türü, süresi ve yoğunluğu belirlenmelidir ${ }^{20}$.

\section{SONUÇ}

Kronik süreçte hastalarda ortaya çıkacak sekeller için rehabilitasyon planı oluşturulurken, hastanın yaşı, komorbid durumları ve hastalığın yarattığı etkiler bütüncül olarak değerlendirilmeli ve bireysel rehabilitasyon programları belirlenmelidir.

COVID-19 sürecinde rehabilitasyonun uzun vadedeki en temel hedefi, kar-zarar analizi yaparak bireyselleștirilmiş bir programda 
hastanın mevcut rehabilitasyon potansiyelini değerlendirerek olası en bağımsız hale gelmesi ve yaşam kalitesinin arttırılmasıdır.

Çıkar Çatışması Beyanı: Yazarlar çıkar çatışması olmadığını bildirmişlerdir.

Finansal Destek: Bu çalışma her hangi bir fon tarafından desteklenmemiştir.

Declaration of ConflictingInterests: The authors declare that they have no conflict of

interest.

Financial Disclosure: No financial support was received.

\section{KAYNAKLAR}

1. Jin YH, Cai L, Cheng zs, et al. A rapid advice guideline for the diagnosis and treatment of 2019 novel coronavirus (2019-nCoV) infected pneumonia (standard version). Mil Med Res. 2020; 7: 4

2. Carda s, Invernizzi M, Bavikatte G, et al. The role of physical and rehabilitation medicine in the COVID19 pandemic: the clinician's view. Ann Phys Rehabil Med. 2020 Apr 18. doi: 10.1016/j.rehab.2020. 04.001 .

3. Xu z, shi L, Wang Y, et al. Pathological findings of COVID-19 associated with acute respiratory distress syndrome. Lancet Respir Med. 2020 Feb 18. doi: 10.1016/ s2213-2600(20)30076-X.

4. Chinese Association of Rehabilitation Medicine, Respiratory rehabilitation committee of Chinese Association of Rehabilitation Medicine, Cardiopulmonary rehabilitation Group of Chinese Society of Physicai Medicine and Rehabilitation. [Recommendations for respiratory rehabilitation of COVID-19 in adult]. Zhonghua Jie He He Hu Xi Za Zhi. 2020;43(0):E029

5. Genç A, Kurtaiş Aytür Y. COVID-19 enfeksiyonunda akut ve postakut pulmoner rehabilitasyon. Ayhan FF, Demirbağ Kabayel D, editörler. COVID-19 Pandemisi ve Fiziksel Tıp ve Rehabilitasyon. 1. Baskı. Ankara: Türkiye Klinikleri; 2020. p.7-12

6. Lim PA, Ng YS, Tay BK. Impact of a viral respiratory epidemic on the practice of medicine and rehabilitation: severe acute respiratory syndrome. Arch Phys Med Rehabil. 2004; 85: 13651370. doi:10.1016/j.apmr.2004.01.022

7. Lin L, Li TS. [Interpretation of "Guidelines for the Diagnosis and Treatment of Novel Coronavirus (2019-nCoV) Infection by the National Health Commission (Trial Version 5)"]. Zhonghua Yi Xue Za Zhi. 2020;100(0):E001. doi:10.3760/cma.j.issn.0376-2491.2020.0001

8. Jones SE, Barker RE, Nolan CM, et al. Pulmonary rehabilitation in patients with an acute exacerbation of chronic obstructive pulmonary disease. J Thorac Dis. 2018; 10 (S12): S1390-S1399. doi:10.21037/jtd.2018.03.18

9. Puhan MA, Gimeno-Santos E, Cates CJ, Troosters T. Pulmonary rehabilitation following exacerbations of chronic obstructive pulmonary disease. Cochrane Airways Group, ed. Cochrane Database of Systematic Reviews. December 2016. doi:10.1002/14651858.CD005305.pub4

10. Yang $\mathrm{F}$, Liu N, Hu JY, et al. [Pulmonary rehabilitation guidelines in the principle of $4 \mathrm{~S}$ for patients infected with 2019 novel coronavirus (2019-nCoV)]. Zhonghua Jie He He Hu Xi Za Zhi. 2020;43(3):180-182. doi:10.3760/cma.j.issn.10010939.2020.03.007 Copyright (C) 2020 Wolters Kluwer Health, Inc. Unauthorized reproduction of this article is prohibited.

11. Huang C, Wang Y, Li X, et al. Clinical features of patients infected with 2019 novel coronavirus in Wuhan, China. Lancet. 2020; 395: 497-506.

12. Özdemir H, Demirbağ Kabayel D. COVID-19 sonrası kardiyak rehabilitasyon. Ayhan FF, Demirbağ Kabayel D, editörler. COVID-19 Pandemisi ve Fiziksel Tıp ve Rehabilitasyon. 1. Baskı. Ankara: Türkiye Klinikleri; 2020. p.20-6

13. Mao L, Jin $H$, Wang $M$, et al. Neurologic manifestations of hospitalized patients with coronavirus disease 2019 in Wuhan, China. JAMA Neurol 2020; 77: 683-90.

14. Araújo BT, Leite JC, Fuzari HK, et al. Influence of high-intensity interval training versus continuous training on functional capacity in individuals with heart failure: A systematic review and metaanalysis. J Cardiopulm Rehabil Prev. 2019; 39: 2938. 
15. Oudkerk M, Büller HR, Kuijpers D, et al. Diagnosis, prevention, and treatment of thromboembolic complications in COVID-19: report of the National Institute for Public Health of the Netherlands. Radiology 2020; 195: 202-7.

16. Magro C, Mulvey JJ, Berlin D, et al. Complement associated microvascular injury and thrombosis in the pathogenesis of severe COVID-19 infection: a report of five cases. Transl Res 2020; 220: 1-13.

17. Mao l, Wang $M$, Mengdie, Chen $S$, et al. Neurological Manifestations of Hospitalized Patients with COVID-19 in Wuhan, China: A Retrospective Case Series Study (February 24, 2020). Available at SSRN: https://ssrn.com/abstract $=3544840$ or http://dx.doi.org/10.2139/ssrn.3544840
18. Jin M, Tong Q. Rhabdomyolysis as Potential Late Complication Associated with COVID-19 [published online ahead of print, 2020 Mar 20]. Emerg Infect Dis. 2020; 26: 10.3201/eid2607.200445. doi:10.3201/eid2607.200445

19. Murat S, Yakşi E. COVID-19 enfeksiyonu ve ağrı yönetimi. Ayhan FF, Demirbağ Kabayel D, editörler. COVID-19 Pandemisi ve Fiziksel Tip ve Rehabilitasyon. 1. Baskı. Ankara: Türkiye Klinikleri; 2020. p.70-4

20. Güneş S, Kutlay Ş. Genel Rehabilitasyon Prensipleri. Memikoğlu 0, Genç V, editör. COVID-19. Ankara Üniversitesi Basımevi; 2020.p.107-12. 